\title{
РОЛЬ ГЕРАЛЬДИКИ В СОВРЕМЕННОЙ ТЕРРИТОРИАЛЬНОЙ ИДЕНТИФИКАЦИИ ГОРОДОВ РЕГИОНА
}

\author{
(c) 2021 Калькова Наталья Николаевна \\ кандидат экономических наук, доцент, \\ доцент кафедры маркетинга, торгового и таможенного дела \\ Институт экономики и управления \\ Крымский федеральный университет им. В.И.Вернадского, Россия, Респ. Крым, Симферополь \\ E-mail: nkalkova@yandex.ru
}

(c) 2021 Митина Элла Александровна

старший преподаватель кафедры маркетинга, торгового и таможенного дела

Институт экономики и управления

Крымский федеральный университет им. В.И.Вернадского, Россия, Респ. Крым, Симферополь E-mail: zhilina_ella@list.ru

\section{(c) 2021 Вельгош Наталия Зиновьевна}

кандидат экономических наук, доцент, доцент кафедры маркетинга, торгового и таможенного дела

Институт экономики и управления

Крымский федеральный университет им. В.И.Вернадского, Россия, Респ. Крым, Симферополь

E-mail: nvelgosh@mail.ru

В статье исследуются вопросы восприятия символов гербов городов региона, формирования ассоциативного ряда с конкретным муниципальным образованием. Представлены результаты социологического опроса относительно узнаваемости и релевантности гербов 14 городов Крыма. Выявлено, что сложность, запутанность и многозначность символов гербов городов может вводить в заблуждение, препятствовать их распознаванию и узнаванию, построению ассоциаций с исследуемыми городами.

Ключевые слова: город, регион, герб, символ, восприятие, социологический опрос, территориальная идентификация, позиционирование.

Введение. Скорость развития городских агломераций в пространственно-временном периоде зависит от качества и объема полученных информационных знаний, специфики системы коммуникаций. Значительные изменения в сфере коммуникации, возможность постоянного доступа к информационным ресурсам обуславливают необходимость оценки восприятия полученной информации потенциальными потребителями городских услуг и принятия на ее основе конкретных решений.

В данных условиях возрастает роль и значение гербов городов в современной территориальной идентификации муниципальных образований региона - как официальных символов, формирующих образ городов при их восприя- тии потенциальными потребителями городских услуг.

Целью исследования является определение роли геральдики в современной территориальной идентификации городов региона. Необходимо определить в какой степени восприятие зависит от символьной информации, присутствующей на гербе муниципального образования, установить особенности его распознавания в системе территориальной идентификации, последующего соотнесения символьной информации со специфическими характеристиками городов. В этой связи в рамках проводимого нами исследования, выдвигается ряд гипотез: гипотеза 1 (Н1): большинство респондентов знают гербы муниципальных образований Крыма;

* Исследование выполнено при финансовой поддержке РФФИ и ЭИСИ в рамках научного проекта № 21-011-31322 
гипотеза 2 (Н2): большинство гербов имеют высокую степень релевантности.

Для всестороннего освещения геральдической проблематики применяются вербальные методы (социологический опрос респондентов, шкала Лайкерта).

Основные результаты. С целью выявления восприятия населением полуострова семиотических знаковых систем, представленных на гербах городов Республики Крым и города Севастополя, нами проведен вербальный опрос. Респондентам представлен стимульный материал в виде гербов 14 территориально-административных единиц региона. Поставлена задача идентифицировать демонстрируемую символику с определенным городом, а, в случае его незнания, по имеющимся символам, предположить, к какой территориальной единице может относиться данный герб. Результаты исследования представлены в таблице 1.

Так установлено, что $76,2 \%$ респондентов не знают какому городу принадлежит геральдический символ Ялты, 16,7\% опрошенных смогли его идентифицировать, а 6,6\% анкетируемых отметили, что это герб г. Судака. Из-за недостаточного понимания представленной символики $42,8 \%$ идентифицировали ее с г. Ялтой, по 3,4\% опрошенных - с городами Судак, Армянск, Бахчисарай, Джанкой, Керчь, Саки и Севастополь. Около $13,4 \%$ анкетируемых отметили, что это герб города Феодосия, а 20\% - города Судака.

Не знают герб города Алушта $80 \%$ респондентов, его смогли идентифицировать только $10 \%$. С уверенностью отметили, что это геральдика г. Керчи и г. Судака 6,7\% и 3,3\% анкетируемых, соответственно. У 29,7\% испытуемых данный символ ассоциируется с г. Алуштой, у 3,4\% - с городами Ялта и Евпатория, а у 23,4\% респондентов - с городами Керчь и Судак.

В ходе демонстрации герба Феодосии толь 3,3\% опрошенных смогли его идентифицировать, по 3,3\% респондентов отметили, что это геральдическая символика городов Евпатория и Керчь, а 13,4\% - г. Севастополя. 76,7\% анкетируемых не смогли распознать ее. В результате ассоциационного восприятия по $10,0 \%$ респондентов отметили, что это герб городов Феодосия и Бахчисарай, по 30\% - городов Керчь и Севастополь, по 6,6\% - городов Армянск и Евпатория, по $3,4 \%$ - городов Джанкой и Судак.

Касательно геральдики города Армянск, то $83,4 \%$ респондентов не знают ее, но 6,4\% опро- шенных смогли ее идентифицировать. Остальные, по 3,4\% анкетируемых определили, что это герб городов Бахчисарай, Джанкой и Красноперекопск. У 6,7\% респондентов данная символика ассоциируется с городами Армянск и Красноперекопском, у 3,4\% - с г. Евпаторией, г. Керчью и г. Саками, у 13,4\% - с г. Джанкоем и г. Судаком. Что данный символ принадлежит городам Феодосия, Армянск и Бахчисарай предположили $16,2 \%, 23,4 \%, 10,00 \%$ опрошенных, соответственно.

Не знают герб Бахчисарая $56,7 \%$ респондентов, смогли идентифицировать его 30\% опрошенных. По 3,4\% опрошенных отметили, что это геральдика городов Армянск и Саки, а 6,5\% г. Джанкоя. Однако, у 3,2\% испытуемых данный символ ассоциируется с г. Алуштой и г. Армянском, у 3,4\% - с г. Красноперекопском, г. Симферополем и г. Старым Крымом, у 6,7\% и 10\% - с городами Джанкой и Саки, соответственно. Большинству анкетируемых (66,7\%) демонстрация данной символики напомнила г. Бахчисарай.

Результаты опроса свидетельствуют, что $56,4 \%$ респондентов не знают к какому городу принадлежит герб г. Джанкоя, однако 23,4\% анкетируемых смогли его идентифицировать: $10 \%$ опрошенных отметили, что это герб г. Красноперекопска, а 3,4\% - г. Бахчисарая, г. Евпатории и г. Саки. В результате незнания представленной символики по 10\% идентифицировали ее с городами Ялта и Красноперекопск, по 6,7\% опрошенных - с городами Феодосия, Евпатория, Саки. По 10\% анкетируемых отметили, что это герб, возможно, городов Алушта, Армянск, Красноперекопск, а 6,5\% - г. Симферополь. У 30\% анкетируемых герб ассоциируется с г. Джанкоем.

В ходе демонстрации герба Евпатории только $23,4 \%$ опрошенных смогли его идентифицировать, 3,4\% респондентов отметили, что это геральдическая символика г. Алушты, 6,5\% г. Феодосии, а $10 \%$ - г. Сак. 56,7\% анкетируемых не смогли распознать ее. В результате ассоциационного восприятия по 6,7\% респондентов отметили, что это герб городов Феодосия и Керчь, по 26,7\% - городов Алушта и Евпатория, а 6,6\% - г. Бахчисарая, 3,2\% - г. Красноперекопска, 20\% - г. Сак, 3,4\% - г. Севастополя.

Геральдическую символику города Керчь не знают $60 \%$ респондентов, но $20 \%$ смогли ее идентифицировать. 6,6\% анкетируемых определили, что это герб г. Феодосии, $13,4 \%$ - г. Севастополя. 

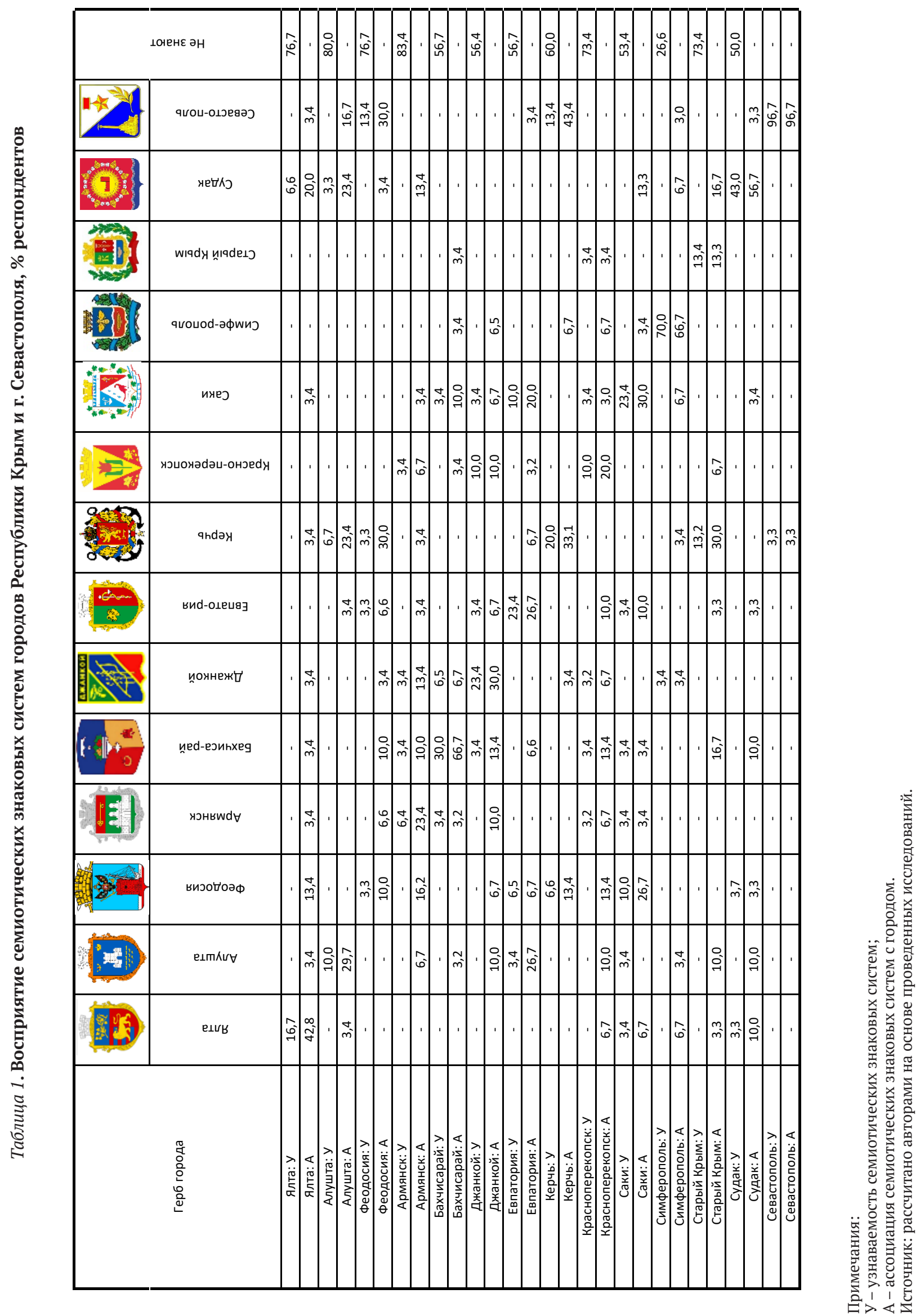
У $13,4 \%$ респондентов данный символ ассоциируется с г. Феодосией, у 3,4\% - с г. Джанкоем, у 33,1\% - с г. Керчью, у 6,7\% - с г. Симферополем, у $43,4 \%$ - с г. Севастополем.

В ходе демонстрации стимульного материала города Красноперекопск 10\% опрошенных смогли идентифицировать герб с городом, по $3,2 \%$ респондентов отметили, что это геральдическая символика городов Армянск, Джанкой, по 3,4\% определили, что данный символ принадлежит городам Бахчисарай, Саки и Старый Крым. 73,4\% анкетируемых не смогли распознать его. В результате ассоциационного восприятия по $6,7 \%$ респондентов отметили, что это герб городов Ялта, Армянск, Джанкой, Симферополь, по 13,4\% - городов Феодосия и Бахчисарай, по 10,0\% - городов Алушта и Евпатория, 20\% г. Красноперекопска, 3,4\% - г. Старого Крыма, 3\% - г. Сак.

Так, 53,4\% респондентов не знают к какой территориально-административной единице принадлежит геральдический символ города Саки, только 23,4\%\% смогли его идентифицировать. По 3,4\% опрошенных отметили, что это герб Ялты, Алушты, Армянска, Бахчисарая, Евпатории, 10\% - г. Феодосии. В результате незнания представленной символики $30 \%$ идентифицировали ее с исследуемым городом, по 3,4\% опрошенных - с городами Армянск, Бахчисарай, Севастополь. 6,7\% анкетируемых отметили, что это герб, возможно, города Ялта, а 26,7\% - г. Феодосии, $10 \%$ - г. Евпатории, 13,3\% - г. Судака.

Герб города Симферополь не знают всего лишь $26,6 \%$ респондентов и большинство опрошенных (70\%) смогли идентифицировать его со столицей г. Джанкоя. Следует отметить, что у 66,7\% испытуемых представленный символ полностью ассоциируется с данной территориально-административной единицей. Однако, по 3,4\% респондентов предположили, что это геральдика городов Алушта, Джанкой и Керчь, по 6,7\% - городов Саки, Судак и Ялта, 3\% - г. Севастополя.

Касательно геральдики города Старый Крым, то $73,4 \%$ респондентов не знают ее, но $13,4 \%$ опрошенных смогли ее идентифицировать. Остальные 13,2\% анкетируемых определили, что это герб г. Керчи. У 3,3\% респондентов данная символика ассоциируется с городами Ялта и Евпатория, у 16,7\% - с г. Бахчисараем и г. Судаком. Что данный символ принадлежит городам Алушта, Керчь, Красноперекопск предположили
$10,0 \%, 30,0 \%, 6,7 \%$ опрошенных, соответственно. Однако 13,3\% испытуемых, символы, представленные на демонстрируемом гербе, сопоставили со Старым Крымом.

Ровно половина опрошенных не знают геральдический символ города Судак, однако, $43,0 \%$ респондентов узнали в нем герб территориально-административной единицы. Незначительная доля анкетируемых предположили, что это геральдика городов Ялта $(3,3 \%)$ и Феодосия $(3,7 \%)$.

Геральдический символ города федерального значения Севастополь идентифицировали 96,7\% респондентов, однако 3,3\% опрошенных обозначили, что демонстрируемый герб принадлежит городу Керчь.

Таким образом, полученные данные полностью опровергают гипотезу 1 (Н1), поскольку из 14 гербов городов респонденты знают только два: г. Симферополя, г. Севастополя.

Следует отметить, что оценка доли узнаваемости символики полностью соответствуют ассоциативному восприятию анкетируемых. Выявлена корреляционная зависимость между узнаваемостью геральдической символики и ассоциативным восприятием городов Республики Крым и г. Севастополя, которая представлена в таблице 2 .

Так, по городу Керчь прослеживается заметная прямая корреляционная связь между узнаваемостью герба и его ассоциацией с муниципальным образованием. По городам Саки, Ялта и Алушта отмечена умеренная прямая корреляционная зависимость. Умеренная обратная связь выявлена по городам Джанкой и Симферополь. Очень высокая корреляционная связь установлена по городу федерального значения Севастополь.

С целью выявления степени релевантности к семиотическим знаковым системам респондентам предложено оценить герб каждого муниципального образования региона по 5 -ти балльной шкале Лайкерта, присвоив тем самым геральдическому символу 1 балл, если анкетируемый считает его абсолютно релевантным, 2 балла «нерелевантный», 3 балла - «затрудняюсь ответить», 4 балла - «релевантный», 5 баллов - «абсолютно релевантный» (таблица 3).

Респонденты, оценившие объект исследования в 1-2 балла, считают его нерелевантным, в 4-5 баллов, соответственно релевантным [2]. Расчет коэффициента релевантности семиоти- 
Таблица 2. Корреляционная связь между узнаваемостью геральдической символики и ассоциацией с городом региона

\begin{tabular}{|l|l|}
\hline \multicolumn{1}{|c|}{ Город } & \multicolumn{1}{c|}{ Узнаваемость / Ассоциации } \\
\hline Ялта & 0,38 \\
\hline Алушта & 0,42 \\
\hline Феодосия & 0,23 \\
\hline Армянск & 0,09 \\
\hline Бахчисарай & 0,27 \\
\hline Джанкой & $-0,30$ \\
\hline Евпатория & 0,25 \\
\hline Керчь & 0,55 \\
\hline Красноперекопск & $-0,21$ \\
\hline Саки & 0,37 \\
\hline Симферополь & $-0,35$ \\
\hline Старый Крым & $-0,22$ \\
\hline Судак & 0,173 \\
\hline Севастополь & 1,0 \\
\hline
\end{tabular}

Источник: рассчитано авторами на основе [1].

Таблица 3. Балльная оценка релевантности геральдической символики городов Республики Крым и г. Севастополя

\begin{tabular}{|l|c|c|c|c|c|}
\hline \multirow{2}{*}{ Город } & \multicolumn{5}{|c|}{ Балльная оценка респондентов, \% } \\
\cline { 1 - 6 } & $\begin{array}{c}1-\text { абсолютно } \\
\text { нерелевантная }\end{array}$ & $\begin{array}{c}2 \text { - нерелевант- } \\
\text { ная }\end{array}$ & $\begin{array}{c}3 \text { - затрудняюсь } \\
\text { ответить }\end{array}$ & $4-$ релевантная & $\begin{array}{c}5-\text { абсолютно } \\
\text { релевантная }\end{array}$ \\
\hline Ялта & 3,3 & 6,7 & 23,3 & 53,3 & 13,3 \\
\hline Алушта & 3,3 & 13,3 & 30,0 & 46,7 & 6,7 \\
\hline Феодосия & - & 13,3 & 26,7 & 26,7 & 33,3 \\
\hline Армянск & 6,7 & 26,7 & 40 & 16,7 & 10,0 \\
\hline Бахчисарай & 20,0 & 26,7 & 26,7 & 16,7 & 10,0 \\
\hline Джанкой & 20,0 & 23,3 & 30,0 & 20,0 & 6,7 \\
\hline Евпатория & 3,3 & 3,3 & 20,0 & 53,3 & 20,0 \\
\hline Керчь & - & 6,7 & 16,7 & 16,7 & 60,0 \\
\hline Красноперекопск & 6,7 & 16,7 & 46,7 & 26,7 & 3,3 \\
\hline Саки & 3,3 & 6,7 & 23,3 & 23,3 & 43,3 \\
\hline Симферополь & 3,3 & 6,7 & 10,0 & 36,7 & 43,3 \\
\hline Старый Крым & 3,3 & 6,7 & 20,0 & 40,0 & 30,0 \\
\hline Судак & 6,7 & 6,7 & 30,0 & 36,7 & 20,0 \\
\hline Севастополь & 6,7 & 3,3 & 26,7 & 20,0 & 43,3 \\
\hline
\end{tabular}

Источник: данные получены в ходе опроса. 
ческих знаковых систем территориально-административных единиц проведен по формуле (1):

$$
K_{p}=P-H,
$$

где: $\mathrm{K}_{\mathrm{p}}$ - коэффициент релевантности; Р количество респондентов, считающих геральдический символ релевантным, \%; Н - количество респондентов, считающих геральдический символ нерелевантным, \%.

Результаты проведенных расчетов представлены в таблице 4.

Коэффициент релевантности может принимать значение от $-100 \%$ до $100 \%$. Высокой степенью релевантности, согласно теории [2], считается показатель в 50\% и выше. Предложено интерпретировать полученные данные согласно шкале, представленной в таблице 5 .

Степень релевантности семиотических знаковых систем городов Республики Крым и г. Севастополя представлена графически (рисунок 1).

Таким образом, респонденты отметили высокую степень релевантности геральдических символов таких территориально-административных единиц как: Ялта (56,6\%), Евпатория (66,7\%), Керчь (70\%), Саки (56,6\%), Симферополь (70\%), Старый Крым (60\%), Севастополь (53,3\%).

Символика городов Алушта, Феодосия, Судак имеет средний уровень релевантности и составляет 36,8\%, 46,7\%, 43,3\%, соответственно. Низкая степень релевантности выявлена у герба города Красноперекопск (6,6\%). Абсолютно нерелевантная, по мнению опрошенных, является геральдическая символика городов Армянск $(-6,7 \%)$, Бахчисарай (-20\%) и Джанкой $(-16,6 \%)$. Таким образом, гипотеза 2 (H2) подтверждена частично.

Заключение. Результаты проведенного исследования относительно знания гербов городов Республики Крым и г. Севастополя, их узнаваемости и ассоциации семиотических знаковых систем с территориально-административными единицами позволили подчеркнуть роль и значение геральдики в современной территориальной идентификации. Выдвинутая нами в ходе исследования гипотеза 1 (H1) о том, что большинство респондентов знают гербы муниципальных образований Крыма, опровергнута. Из 14 гербов городов Республики Крым и г. Севастополя сформировались знания о них у жителей только двух городов - Симферополя и Севастополя. Однако большинство гербов имеют высокую степень релевантности, что в ходе исследования было установлено и позволило частично подтвердить выдвинутую гипотезу 2 (H2).

Городским агломерациям в условиях жесткой конкурентной борьбы на внешнем и внутреннем рынках за различные виды материальных и нематериальных ресурсов, необходимо использовать новый прогрессивный подход, который будет обеспечивать условия для эффективного

Таблица 4. Показатели степени релевантности семиотических знаковых систем городов Республики Крым и г. Севастополя

\begin{tabular}{|l|c|c|c|}
\hline \multirow{2}{*}{ Город } & \multicolumn{2}{|c|}{ Показатели } \\
\cline { 2 - 4 } & Нерелевантный, \% & Релевантный, \% & $\begin{array}{c}\text { Коэффицент релевант- } \\
\text { ности, \% }\end{array}$ \\
\hline Ялта & 10,0 & 66,6 & 36,6 \\
\hline Алушта & 16,6 & 53,4 & 46,8 \\
\hline Феодосия & 13,3 & 60,0 & $-6,7$ \\
\hline Армянск & 33,4 & 26,7 & $-20,0$ \\
\hline Бахчисарай & 46,7 & 26,7 & $-16,6$ \\
\hline Джанкой & 43,3 & 26,7 & 66,7 \\
\hline Евпатория & 6,6 & 73,3 & 70,0 \\
\hline Керчь & 6,7 & 76,7 & 6,6 \\
\hline Красноперекопск & 23,4 & 30,0 & 56,6 \\
\hline Саки & 10,0 & 66,6 & 70,0 \\
\hline Симферополь & 10,0 & 80,0 & 60,0 \\
\hline Старый Крым & 10,0 & 70,0 & 43,3 \\
\hline Судак & 13,4 & 56,7 & 53,3 \\
\hline Севастополь & 10,0 & 63,3 & \\
\hline
\end{tabular}

Источник: рассчитано авторами. 
Таблица 5. Интерпретация степени релевантности семиотических знаковых систем городов Республики Крым и г. Севастополя

\begin{tabular}{|c|l|}
\hline Показатель & \multicolumn{1}{|}{ Характеристика степени релевантности } \\
\hline $75-100$ & Абсолютно релевантный \\
\hline $51-74$ & Высокая степень релевантности \\
\hline $25-50$ & Средняя степень релевантности \\
\hline $0-24$ & Низкая степень релевантности \\
\hline$<0$ & Нерелевантный и абсолютно нерелевантный \\
\hline
\end{tabular}

Источник: предложено авторами.

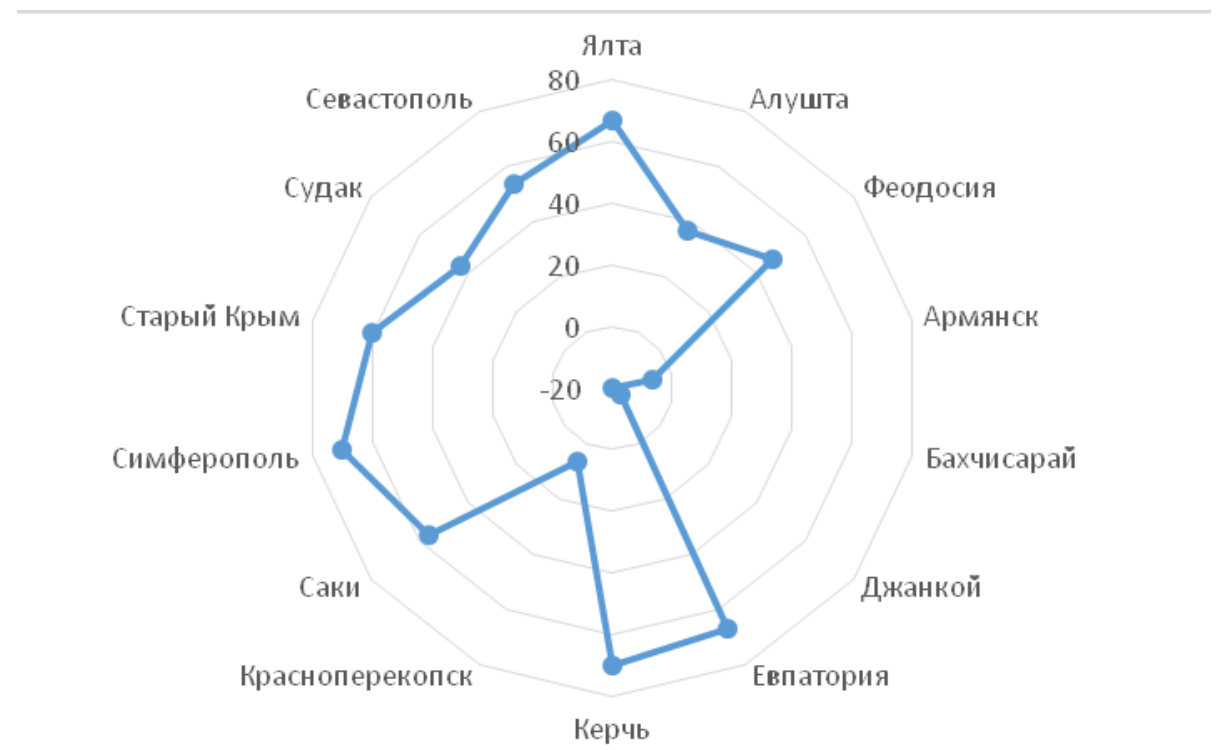

Рисунок 1. Степень релевантности семиотических знаковых систем городов Республики Крым и г. Севастополя Источник: рассчитано авторами.

внедрения изменений, продуцирования прогрессивных идей, преодоления консервативных стереотипов. Продвигаемая о городе и его характеристиках, конкурентных преимуществах информация должна быть верно интерпретирована социумом для привлечения и удержания на территории различных видов ресурсов, что, в итоге, будет способствовать устойчивому долгосрочному социально-экономическому развитию городской экосистемы.

Для привлечения необходимых ресурсов в процессе развития городского пространства не- обходимо искать новые приоритеты, которые связаны с формированием как национальных, так и личных ценностей на основе критического анализа ценностных ориентиров и определения взаимосвязи информационных ресурсов и личностной культуры человека для усиления их территориальной идентичности. Продвижение города с использованием геральдических символов требует формирования и закрепления такого образа, который бы информировал и заинтересовывал посетить данную территорию.

\section{Библиографический список}

1. Chaddock R.E. Principles and Methods of Statistics. Houghton Miffin Company, Cambridge : The Riverside Press, $1925.471 \mathrm{p}$.

2. Wilson Deirdre, Sperber Dan (2004). Relevance Theory/ In: Handbook of Pragmatics. Ed. by Laurence R. Horn and Gregory L. Ward. Oxford. pp. 249-290. 